\title{
Ethnozoology in Brazil: analysis of the methodological risks in published studies
}

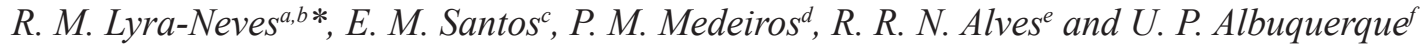 \\ aPrograma de Pós-graduação em Etnobiologia e Conservação da Natureza, Departamento de Biologia, \\ Universidade Federal Rural de Pernambuco - UFRPE, Rua Dom Manoel de Medeiros, s/n, \\ Dois Irmãos, CEP 52171-900, Recife, PE, Brazil \\ bUnidade Acadêmica de Garanhuns, Universidade Federal Rural de Pernambuco - UFRPE, Av. Bom Pastor, \\ s/n, Boa Vista, CEP 55292-270, Garanhuns, PE, Brazil
}

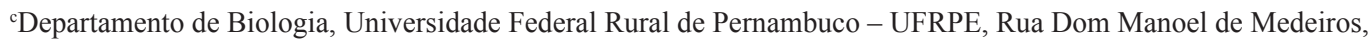
s/n, Dois Irmãos, CEP 52171-900, Recife, PE, Brazil

'Instituto de Ciências Biológicas e Desenvolvimento Sustentável, Universidade Federal do Oeste da Bahia - UFOB, Estrada do Barrocão, s/n, Morada Nobre, CEP 47800-000, Barreiras, BA, Brazil

eDepartamento de Biologia, Universidade Estadual da Paraíba - UEPB, Av. das Baraúnas, 351, Bodocongó, CEP 58109-753, Campina Grande, PB, Brazil

'Laboratório de Etnobiologia Aplicada e Teórica, Programa de Pós-graduação em Etnobiologia e Conservação da Natureza, Departamento de Biologia, Universidade Federal Rural de Pernambuco - UFRPE, Rua Dom Manoel de Medeiros, s/n, Dois Irmãos, CEP 52171-900, Recife, PE, Brazil

*e-mail: rmlneves@uag.ufrpe.br

Received: May 12, 2014 - Accepted: October 1, 2014 - Distributed: November 30, 2015

(With 1 figure)

\begin{abstract}
There has been a growth in the field of Ethnozoology throughout the years, especially in Brazil, where a considerable number of scientific articles pertaining to this subject has been published in recent decades. With this increase in publications comes the opportunity to assess the quality of these publications, as there are no known studies assessing the methodological risks in this area. Based on this observation, our objectives were to compile the papers published on the subject of ethnozoology and to answer the following questions: 1) Do the Brazilian ethnozoological studies use sound sampling methods?; 2) Is the sampling quality influenced by characteristics of the studies/publications? The studies found in databases and using web search engines were compiled to answer these questions. The studies were assessed based on their nature, sampling methods, use of hypotheses and tests, journal's impact factor, and animal group studied. The majority of the studies analyzed exhibited problems associated with the samples, as $144(66.98 \%)$ studies were classified as having a high risk of bias. With regard to the characteristics analyzed, we determined that a quantitative nature and the use of tests are essential components of good sampling. Most studies classified as moderate and low risk either did not provide these data or provided data that were not clear; therefore, these studies were classified as being of a quali-quantitative nature. Studies performed with vertebrate groups were of high risk. Most of the papers analyzed here focused on fish, insects, and/or mollusks, thus highlighting the difficulties associated with conducting interviews regarding tetrapod vertebrates. Such difficulties are largely related to the extremely strict Brazilian laws, justified by the decline and extinction of some species, related to the use of wild tetrapod vertebrates.
\end{abstract}

Keywords: scientometry, Ethnobiology, Ethnoecology, methodological biases.

\section{Etnozoologia no Brasil: análise de riscos metodológicos nos trabalhos publicados}

\section{Resumo}

Ao longo dos anos a Etnozoologia vem crescendo, principalmente no Brasil, no qual se observa um expressivo número de publicações científicas nas últimas décadas. Com isto abriu-se a oportunidade para avaliar a qualidade das publicações, já que não existem pesquisas que avaliem os riscos metodológicos na área. Partindo desta premissa objetivamos compilar os artigos publicados na área e responder as seguintes questões: os trabalhos etnozoológicos brasileiros possuem boa qualidade amostral? A qualidade amostral é influenciada por características dos estudos/publicações? Para responder tais perguntas foi realizado levantamento das publicações em bases de dados e sites de busca. As características avaliadas foram relacionadas à natureza, amostragem, uso de hipóteses e testes, fator de impacto do periódico e grupo animal 
pesquisado. A maior parte dos artigos analisados apresentaram problemas amostrais, 144 (66,98\%) foram classificados como sendo de alto risco de viés. Quanto às características analisadas percebemos que a natureza quantitativa e a utilização de testes, são essenciais para uma boa amostragem. A maioria das publicações classificada com moderado e baixo risco não apresentava ou não deixava claro esses dados, sendo classificadas como de natureza quali-quantitativa. Percebemos também que artigos desenvolvidos com grupos vertebrados apresentaram alto risco, levando a crer que as restrições da legislação brasileira limitam as informações mais precisas a respeito do tema.

Palavras-chave: cienciometria, Etnobiologia, Etnoecologia, vieses metodológicos.

\section{Introduction}

A large quantity of noteworthy ethnozoological research has been conducted in Brazil to date, bringing this country into the spotlight in this field, as Brazil is now considered one of the most important sources worldwide of scientific production in this area (Alves and Souto, 2011). Alves and Souto (2011) suggest that this productivity is due to the inclusion of specialists in superior education institutions and to the addition of specific courses to undergraduate and graduate programs, creating increased interest among young researchers.

The Brazilian studies indicate considerable diversity in knowledge and uses of the fauna, which vary with the conditions of each area or locality and which are also related to the different life forms and ecosystems, as well as to cultural diversity (Alves and Souto, 2011).

Current ecological themes also present a variety of approaches, especially regarding the different uses of wild fauna (Nishida et al., 2006; Alves and Santana, 2008; Alves et al., 2010a, b; Favoretto et al., 2011; Ritter et al., 2012). The use of fauna-derived products in popular medicine (zootherapy) has been the most studied subject, which encompasses studies performed in traditional Brazilian communities, especially in Brazil's northern and northeastern regions (Alves and Rosa, 2007; Alves et al., 2007; Alves, 2008).

Overall, it can be said that a great part of ethnozoological research addresses invertebrate groups, particularly crustaceans and insects (see Alves and Dias, 2010; Ulysséa et al., 2010; Alencar et al., 2012; Nascimento et al., 2012). Regarding vertebrates, most of the studies are performed on fish (see Mourão and Nordi, 2006; Clauzet et al., 2007; Silvano and Valbo-Jørgensen, 2008; Lopes, et al., 2009; Begossi et al., 2012).

Most of the ethnozoological papers published since 1996 are of a descriptive nature (Alves, 2009; Alves and Alves, 2011). There has been a growth in quantitative research; however, there is a need for improvement in the publications and for more scientifically rigorous studies that include specific questions and hypotheses, to contribute to the advancement of ethnozoology in Brazil (Alves and Souto, 2011). In addition, these studies should be guided by logic and by the sample's adequacy (Medeiros et al., 2014). Although qualitative research has countless orientations and assumptions, quantitative research is directly associated with positivist logic. Moreover, the quality of sampling may be easily evaluated, as information tends to be generalized according to the interests of the researcher (Medeiros et al.,
2014). In some instances, qualitative research requires the use of intentional sampling, as it guarantees that the researcher will obtain more precise information on the study theme (Marshall, 1996). According to Bartlett et al. (2001), even studies that do not include statistical analyses in their final text should define the ideal sample size.

Sampling design is a fundamental part of planning a scientific study, and quantitative sampling requires hypothesis testing, which is used in the search for behavioral patterns as well as for comparisons between studies performed as part of either the same study or different studies (Alves and Souto, 2011).

The use of appropriate sampling techniques contributes to the formulation of future research and to a better understanding of the sampling population. Conversely, either a lack of adequate planning or planning that does not use such techniques may lead to high methodological risk and constitute a source of bias (Bartlett et al., 2001; Medeiros et al., 2012) by masking behavioral patterns and inadequately recording the internal diversity of the sampling population (Medeiros et al., 2012). These problems may also be observed in other areas of science, revealing errors related to the sampling design and compromising the study's results and conclusions (see Bartlett et al., 2001; Lee, 2010). Many studies use incorrect or questionable approaches for the selection of sampling size; thus, methodological improvement in this area is required.

Still, according to Bartlett et al. (2001), misguided sampling or negligence of the adopted principles is common, as these issues are observed in scientific studies dealing with interviews or access to knowledge as well (see Bartlett et al., 2001; Medeiros et al., 2012). Therefore, a robust sampling design must be applied to guarantee the randomness of the sample, allowing correct interpretations to be made and mistaken conclusions regarding the described patterns to be avoided (Bartlett et al., 2001; Medeiros et al., 2012). Different techniques are employed to draw conclusions about different aspects of a given population, based on samples or on a part of the specific group (Albuquerque et al., 2014).

Evaluations of ethnobotanical studies have shown that sampling problems are associated with many of these studies, indicating that a large portion of intra-cultural diversity may not have actually been captured by these studies (Medeiros et al., 2014). Medeiros et al. (2014) proposes different evaluation criteria, based on bias risk, to evaluate the published ethnobotany papers. A methodological element of the related field of ethnozoology is access to 
information through interviews with human beings, and it is possible that this element is being neglected, resulting in misguided sampling information and subsequent sampling problems. With this issue in mind, this study intends to assess the methodological risks found in ethnozoological studies published since 1996 by answering the following questions: 1) Do Brazilian ethnozoological studies use sound sampling methods? 2) Is the sampling quality influenced by characteristics of the studies/publications?

\section{Material and Methods}

We performed a bibliographical survey of papers published in the last 17 years (1996-2012). We established these limits because most of the papers on ethnozoology have been published in the last 10 years (Alves and Souto, 2011) and because limitations exist with regard to older publications in the databases.

Our research included papers reporting original research performed in Brazil with wild animals. These studies were related to local knowledge and to the use of the fauna, for example, for hunting (feeding, commerce, domestication), zootherapy (production, use and commerce of animal-derived medicine), and mystical use. We only used papers published in national or international scientific journals. Theses, dissertations, books, and book chapters were not included in the sample.

To perform the bibliographical survey, we consulted the databases Scielo, Scirus, and Scopus, in addition to the search engines Google and Google Scholar. The publication "Ethnozoology in Brazil: current status and perspectives" (Alves and Souto, 2011) compiles all papers on ethnozoology research conducted in Brazil and published before 2011. Therefore, to avoid leaving out any study pertaining to the survey's objectives, we also considered the papers cited in this publication that were not found in previous searches and that comply with the established criteria. In our literature search, we used key words relating to ethnozoology and animal groups associated with the term "Brazil", in both Portuguese and English, in order to guarantee the inclusion of the largest possible number of papers. These terms included Ethnozoology + Brazil; Etnozoologia + Brasil; Traditional knowledge; Conhecimento tradicional; Ethno + reptiles + Brazil; Etno + répteis + Brasil; Cinegetic Activities; Atividades Cinegéticas; Animal Use + Local Knowledge + Brazil; Uso Animal + Conhecimento Local + Brasil.

We opted to follow the recommendations given by Medeiros et al. (2014) regarding the analysis process. Therefore, for each paper included in the analysis, we assessed the following:

Nature of the study (qualitative, quali-quantitative, or quantitative): The nature of the research, as mentioned above, may show methodological problems due to erroneous application of the methods. A large part of qualitative studies bring forth quantitative results that were not proposed from the start. Therefore, a larger number of quali-quantitative than quantitative studies are expected to be classified as high risk. For this classification, the risks associated with studies that had quantitative data were assessed, as purely qualitative studies could not be analyzed by positivist criteria.

Presentation of hypotheses (yes or no) and application of tests (yes or no): We believe that studies that use a good sampling design, including presentation of hypotheses and application of consistent statistical tests or indices, would have a smaller methodological risk.

Sample (intentional or probabilistic): In most papers, the choice to use probabilistic samples reveals considerable errors in the application of this method. Errors are due to the failure to specify randomness, suggesting a tendency of high risk of bias for this sampling method.

Journal where the paper was published (international or national): In general, international journals tend to be more valued; therefore, a smaller risk of bias would be expected of the papers published in international versus national journals.

Quality of the journal where the paper was published: Journal quality was evaluated according to the journal's impact factor, as classified by Journal Citation Reports (JCR). Greater rigor in manuscript evaluation and a consequently smaller risk of bias would be expected for journals with impact factors greater than one (1.0).

Animal group (tetrapods $\times$ invertebrates and fish $\times$ all): It is believed that, because Brazilian law is stricter regarding wild tetrapod groups, most of the studies emphasizing this group would be considered to have a high risk of bias due to greater sampling difficulties.

We highlight that all of the analyzed papers related to Brazilian wild fauna were evaluated under the premise of contemplating all study methods. After characterizing the papers, we separated them according to the criteria proposed by Medeiros et al. (2014) and recorded the percentage of bias (high, moderate, and low) for each of the papers analyzed (see Medeiros et al., 2014).

We performed the G-test (Zar, 1996) after constructing $2 \mathrm{xn}$ and $3 \mathrm{xn}$ contingency tables in Excel. We performed all tests using the statistical software BioEstat 5.0 (Ayres et al., 2007), and values were considered significant at $\mathrm{p} \leq 0.05$.

\section{Results}

We assessed 215 scientific papers that complied with the criteria established for our research. Of these papers, $144(66.98 \%)$ were classified as having a high risk of bias, $54(25.11 \%)$ were classified as having a moderate risk and $17(7.91 \%)$ were classified as having a low risk (Table 1$)$. Of the papers analyzed here, only eight explicitly followed the hypothetic-deductive logic. Five of these papers were of high risk, two of moderate risk, and one of low risk.

As to the nature of the research, 83 papers were explicitly classified as being of a qualitative nature, whereas three were classified as quantitative (Figure 1). We also classified 129 papers as being of a quali-quantitative nature. Although these papers reported the findings from qualitative research, they also presented quantitative results that had not been proposed in the study's objectives and methods. 
Table 1. Numbers and percentages indicating methodological bias of the analyzed papers.

\begin{tabular}{ccccccccc}
\hline Risks Criteria & C1 & C2 & C3 & C4 & C5 & C7 & N & \% \\
\hline Low & 2 & 1 & 2 & 12 & 0 & 0 & 17 & 7.91 \\
Moderate & 8 & 1 & 1 & 42 & 2 & 0 & 54 & 25.11 \\
High & 29 & 0 & 8 & 104 & 0 & 3 & 144 & 66.98 \\
N & 39 & 2 & 11 & 158 & 2 & 3 & 215 & 100 \\
$\%$ & 18.14 & 0.93 & 5.12 & 73.49 & 0.93 & 1.39 & 100 & \\
\hline
\end{tabular}

C1-Nature of the study; C2 - Presentation of hypotheses; C3 - Sample; C4 - Journal where the paper was published; C5 - Quality of the journal where the paper was published; C6 anda C7 - Animal group.

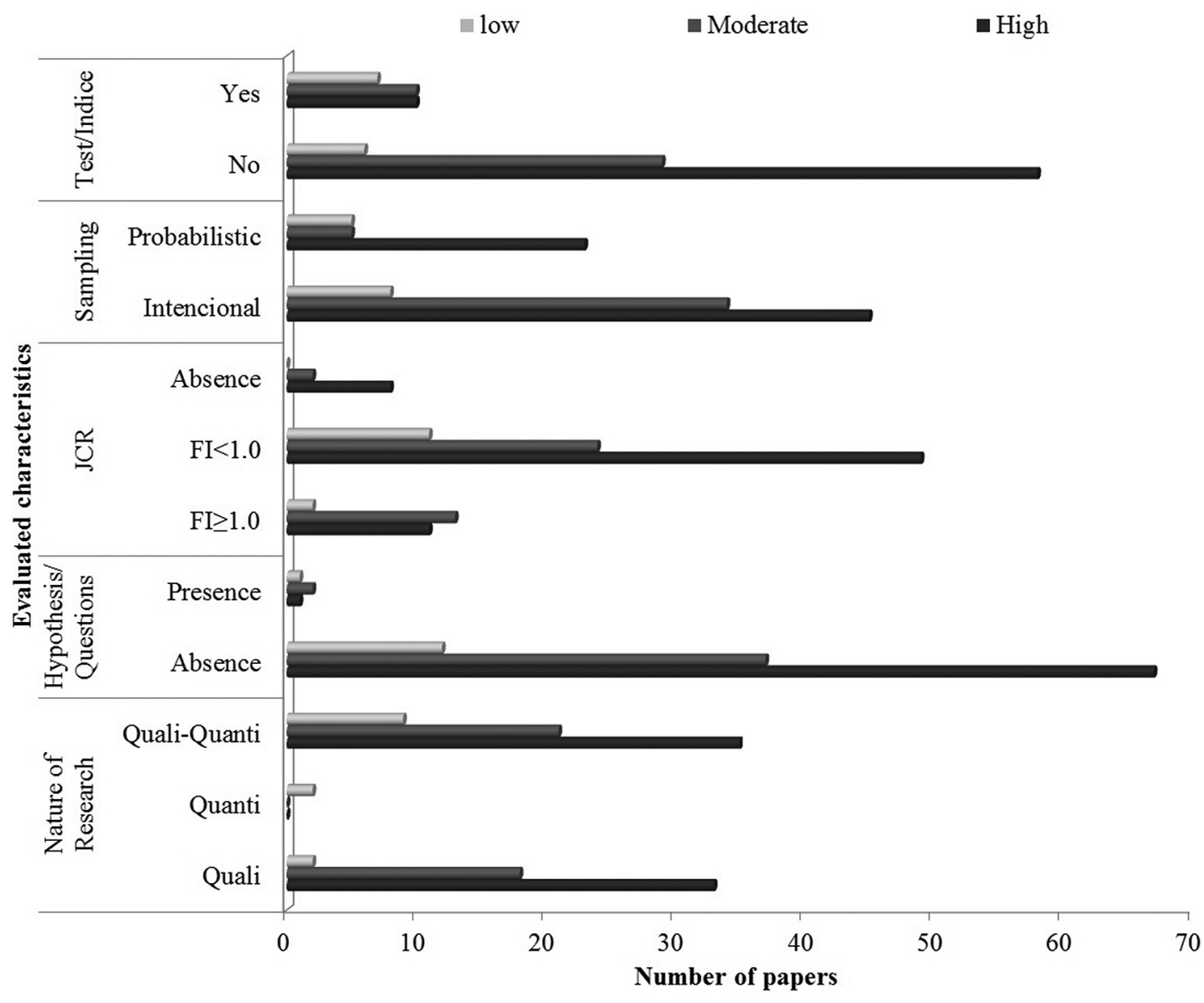

Figure 1. Number of studies and bias risks (high, moderate and low) related to the study parameters (nature, hypotheses/ tests, sample, journal, JCR, animal group).

Regarding the papers of a quali-quantitative nature, $89(67.42 \%)$ were classified as having a high risk of bias, followed by $31(23.49 \%)$ classified as moderate risk and only $12(9.09 \%)$ classified as low risk. We noted that all quantitative studies were classified as having a low risk of bias (Figure 1). A larger number of the quali-quantitative studies were classified as high and moderate risk (Figure 1), as seen in Table 2. As for the qualitative studies $(\mathrm{N}=83)$, $66.3 \%$ were considered high risk, $27.7 \%$ were moderate risk and $6 \%$ were low risk.

We classified 172 papers as having used intentional sampling, all of which used the snowball technique to select the informants. Of these studies, 114 (66.28\%) were classified as high risk, 46 (26.74\%) as moderate risk, and $12(6.98 \%)$ as low risk (Figure 1). The other studies $(n=43)$ clearly demonstrated that they used probabilistic sampling; $30(69.77 \%)$ of these were high risk, eight (18.6\%) were moderate risk, and five (11.63\%) were low risk (Figure 1). Although we noticed a greater percentage of studies with a high risk of bias among those that used probabilistic sampling than among those that used intentional sampling, the G-test showed that this difference was not significant (Table 2). 
Table 2. G-test: comparison between risks (high, moderate, low) and parameters analyzed (nature, hypotheses/tests, sample, journal, JCR, animal group). Values with alpha $\leq 0.05$ are highlighted.

\begin{tabular}{ccccccc}
\hline & Nature & Hypothesis & IF-JCR & Sample & Tests & Groups \\
\hline $\mathrm{N}$ & 132 & 215 & 215 & 215 & 215 & 213 \\
DF & 2 & 2 & 4 & 2 & 2 & 4 \\
G-Test & 15.1404 & 0.2149 & 5.2205 & 1.8906 & 5.8209 & 16.6266 \\
(p) & 0.0005 & 0.8981 & 0.2654 & 0.3886 & 0.0545 & 0.0023 \\
& Nature & Hypothesis & IF-JCR & Sample & Tests & Groups \\
N & 132 & 215 & 215 & 215 & 215 & 213 \\
DF & 1 & 1 & 2 & 1 & 1 & 2 \\
G-Test & 6.8753 & 0.0738 & 0.2125 & 0.1914 & 1.2067 & 9.2846 \\
(p) & 0.0087 & 0.7859 & 0.8992 & 0.6617 & 0.272 & 0.0096 \\
\hline
\end{tabular}

Among the studies analyzed here $(\mathrm{n}=215)$, only eight included questions or hypotheses, and 68 used statistical tests and/or indices. Regarding risk, five (62.5\%) papers that presented hypotheses were classified as having a high risk of bias, two (25\%) were classified as intermediate risk, and one was classified as low risk (12.5\%). Among the studies lacking hypotheses, $139(67.15 \%)$ were classified as high risk, $54(25.12 \%)$ as moderate risk, and $16(7.73 \%)$ as low risk. Notwithstanding the large number of papers with no hypotheses, the proportion of risk levels was similar to that of the studies that included hypotheses, indicating that there were no significant differences in risk of bias between studies with and without hypotheses (Table 2).

Regarding the studies that used statistical tests or indices, we observed that $42(61.76 \%)$ were classified as high risk, 16 (23.53\%) as moderate risk, and 10 (14.71\%) as low risk. Of those studies that did not use statistical tests or indices, $102(69.39 \%)$ were classified as high risk, $38(25.85 \%)$ as moderate risk and seven $(4,76 \%)$ as low risk. The proportion of low risk studies was greater among the studies that used statistical tests and/or indices, as indicated by the statistically significant difference determined by the G-test (Table 2).

We also assessed the relationship between risk and the journals' impact factors (IF), measured by JCR. Most of the studies were published in journals with $\mathrm{IF}=1.0$ or lower, and some were published in journals that did not have an associated impact factor $(\mathrm{n}=21)$. Among the studies we evaluated, 68 were published in journals with $\mathrm{IF} \geq 1.0$. Of the studies published in journals with IF $\geq 1.0,47$ (69.12\%) were classified as high risk, 17 (25\%) as moderate risk, and four (5.88\%) as low risk. Regarding studies published in journals with IF $<1.0,83(65.87 \%)$ were of high risk, $30(23.81 \%)$ were of moderate risk and $13(10.32 \%)$ were of low risk. Of the papers without an associated impact factor, $14(66.67 \%)$ were high risk and seven $(33.33 \%)$ were moderate risk; there were no low risk studies in this group. Although we observed a greater proportion of low and moderate risk studies among those with an associated JCR impact factor, these differences were not significant (Table 2).

We also assessed the possible differences in risk of bias among the animal groups studied in the analyzed papers.
Of the papers analyzed here, 94 focused on tetrapod animal species, 57 focused on invertebrates and fish, and 62 dealt with all animal groups in the research. We observed that, among the studies with tetrapods, 57 (60.64\%) were classified as high risk, 14 (14.89\%) as moderate risk, and $23(24.47 \%)$ as low risk (Figure 1). Of the studies dealing with invertebrates and/or fish, 36 (63.16\%) were high risk, five $(8.77 \%)$ were moderate risk, and $16(28.07 \%)$ were low risk (Figure 1). Of the papers that dealt with all animal groups, 51 (82.26\%) were high risk, eight (12.90\%) were moderate risk, and three (4.84\%) were low risk (Figure 1). We also assessed the relationships between the animal groups and the three levels of bias risk, as well as for high risk compared to intermediate and low risk. For all of these relationships, we observed highly significant differences in bias risk between the study groups (Table 2).

\section{Discussion}

Most ethnozoological studies performed in Brazil still have a descriptive focus, and the criteria used in their sampling, such as the nature and type of the sample (intentional or probabilistic), are not always clear. Moreover, most studies do not provide the sampling information, making these analyses much more difficult. Similar findings have been described for other areas of science, suggesting that ethnozoology is not the only area in which a lack of attention is given to sampling (Kitson et al., 2001); however, in line with our observations, Medeiros et al. (2014) comments that sampling problems are not the greatest issue associated with ethnobotanical studies performed in Brazil, as the lack of information on sample size and population are of greater concern. Although the field of ethnozoology is younger than that of ethnobotany, both have similar requirements with regard to attention to sampling design. Ethnozoology has made important contributions to a variety of areas of knowledge, such as anthropology, biomedicine, and human ecology (see Favoretto et al., 2011; Ritter et al., 2012). These sciences have been classified as empirical throughout history (Santos-Fita and Costa-Neto, 2007).

The studies of a quantitative nature that were classified as low risk were generally published more recently (Alves and Rosa, 2007; Alves et al., 2007; Alves, 2008); 
however, many recent papers still contain problems related to the information available on sampling, which greatly complicates a more robust analysis and the search for ethnozoological and/or ethnoecological patterns in different regions of Brazil. These problems have also been observed in ecological publications (Kitson et al., 2001) related to research involving animal communities, demonstrating the difficulties associated with proposing ecological patterns in species richness between different areas due to a lack of information or erroneous sampling.

Although there has been an increase in the number of studies using the hypothetico-deductive method in recent years, as noted by Alves and Souto (2011), we determined that this increase is small with regard to explicitly quantitative studies. According to Alves and Souto (2011), as well as to Araujo and Nishida (2007), it will be necessary to invest in quali-quantitative studies with numerically reliable data to strengthen the field of ethnozoology in Brazil.

We understand that these recommendations necessarily include studies that used quantitative or even quali-quantitative approaches, but whose sampling universe and size are not clear from the methods. The major issue associated with these analyses is that the nature of the research or the criteria used for sample selection are not clear in the majority of the ethnozoological studies performed in Brazil (see Kitson et al., 2001; McClatchey, 2006). Studies of a qualitative nature are very important, as indicated by Dixon-Woods et al. (2004); however, when these studies extrapolate descriptions and present quantitative data without pre-established criteria, they generate bias. There is, therefore, a need to establish criteria to enable a more efficient comparative evaluation (Alves et al., 2010c) in the search for patterns, thereby preventing errors such as those observed and described in our analyses.

We did not compare the risks of the qualitative studies because we believe that such studies should not be analyzed by positivist criteria; however, we noticed that a large number of papers classified as high risk gave either unclear or no information about the sampling universe and size. Qualitative research is, in general, still of a descriptive nature and is the choice method used by many scientists (Alves et al., 2008, 2010c). In addition, qualitative research often concerns a parameter that cannot be quantified, answering very particular questions and dealing with meanings, beliefs, and values related to phenomena that cannot be reduced to variable operationalization (Deslandes et al., 1994). Therefore, depending on the objectives, qualitative research may be a more adequate method (Spindola and Santos, 2003).

Most of the studies classified as having a high risk of bias used intentional sampling. Although there were no significant differences, we noticed that a smaller proportion of studies with probabilistic sampling were classified as having a low risk of bias. Among the studies that used intentional sampling, 15 extrapolated their findings to the general community, indicating that they should have used probabilistic sampling. Such choices may lead to errors in interpreting the patterns found in these studies. Great progress has been observed in theoretical and practical studies of sampling since the mid-20th century, including the realization that statistics is an important analysis tool in research (Marks, 1951); however, the misuse of this tool may lead to inexact and meaningless conclusions. Thus, if the sample is restricted to a certain group, the conclusions must also be restricted; speculations about the applicability to other populations are appropriate and valuable, but it should be made clear that they are only speculations (Marks, 1951).

Most of the studies analyzed here did not include questions and/or hypotheses, and few employed statistical tests and/or indices. Even so, we observed that a greater proportion of the studies that used statistical tests and/or indices were classified as low risk, although some studies with a high risk of bias also used such tests. Our findings are in agreement with Bartlett et al. (2001), who state that even studies that use statistical tests can contain considerable errors.

Although we expected the scientific journals in which the studies were published to be among the parameters showing the greatest differences in terms of risk of bias, this was not the case, as there were no significant differences in this portion of our analysis. Most studies that were classified as high risk were published in journals with IF $\geq 1$. 0 , which was also observed for the studies classified as moderate and low risk. Our results corroborate the findings of Medeiros et al. (2014) regarding ethnobotanical studies, as this author also did not find significant differences between journal types classified according to the JCR impact factors; however, ethnobotanical studies submitted to highly ranked scientific journals are rejected primarily because their methods are not presented in sufficient detail (McClatchey, 2006), which contradicts our results and those obtained by Medeiros et al. (2014). In our study, we observed that, for ethnozoological studies, publication in high-ranking journals does not influence the risk of bias, as studies with methodological problems are often accepted and published.

Most of the papers analyzed here focused on fish, insects, and/or mollusks, thus highlighting the difficulties associated with conducting interviews regarding tetrapod vertebrates. Such difficulties are largely related to the extremely strict Brazilian laws, justified by the decline and extinction of some species, related to the use of wild tetrapod vertebrates (Brasil, 1998). Themes related to ichthyology (fish) and entomology (insects) represent a significant proportion of the published ethnozoological studies, which may be attributed to the importance of these groups or, more likely, to the lack of excessive legal restrictions of the use of these animals (Alves and Souto, 2011). This lack of legal restrictions makes information pertaining to these animals more accessible, as the informants do not show distrust or fear of suffering the penalties imposed by the law. In addition, many interviewees do not trust the researchers, which may compromise the studies' results (Alves and Souto, 2011). As such, we believe that there may a be a 
difference in risk of bias between studies related to wild tetrapod vertebrates and those related to other animals. This hypothesis was corroborated by statistical tests, which showed highly significant differences regarding risk between studies. This observation shows that, among the studies analyzed here, those related to tetrapods generally had a higher risk of bias than those related to other groups.

The large number of papers vulnerable to a high degree of bias is related to the lack of details presented on the methodological procedures adopted in each study, such as the sampling approach or even sample size. Without a doubt, these problems may have serious consequences for the reliability of the conclusions of each study. Given this, we believe that the ongoing growth of ethnozoological research in Brazil reinforces the need for the more systematic description of methodological procedures adopted in each study, in order to guarantee greater precision and robustness, irrespective of whether the study is qualitative or quantitative. It would thus be recommendable that all papers, whatever the sampling procedures or techniques used in the respective study, present all relevant information on these procedures, in order to confirm that the research has satisfied the minimum requirements expected for each approach, as well as guaranteeing that the conclusions and interpretations derived from the data are coherent with the limitations of the methods applied.

\section{Acknowledgements}

We thank the Laboratory of Applied and Theoretical Ethnobiology (LEA), in which the research and data analysis used for this manuscript was conducted by RMLN and EMS. We also thank all of our friends from LEA for the harmonious companionship and support during the development of this study. To CNPq (National Council for Scientific and Technological Development) for the research support and productivity scholarships granted to UPA and RRNA. This paper is contribution PXX of the Rede de Investigação em Biodiversidade e Saberes Locais (REBISA-Network of Research in Biodiversity and Local Knowledge), with financial support from FACEPE (Foundation for Support of Science and Technology) to the project Núcleo de Pesquisa em Ecologia, conservação e Potencial de Uso de Recursos Biológicos no Semiárido do Nordeste do Brasil (Center for Research in Ecology, Conservation and Potential Use of Biological Resources in the Semi-Arid Region of Northeastern Brazil - APQ1264-2.05/10)

\section{References}

ALBUQUERQUE, U.P., LUCENA, R.F.P., CUNHA, L.V.F.C. and ALVES, R.R.N., 2014. Methods and techniques in ethnobiology and ethnoecology. New York: Springer. 476 p. vol. 1. http://dx.doi. org/10.1007/978-1-4614-8636-7.

ALENCAR, J.B.R., SILVA, E.F., SANTOS, V.M., SOARES, H.K.L., LUCENA, R.F.P. and BRITO, C.H., 2012. Percepção e uso de "insetos" em duas comunidades rurais no semiárido do Estado da Paraíba. BioFar, vol. 9, pp. 72-91.
ALVES, R R.N. and DIAS, T.L.P., 2010. Usos de invertebrados na medicina popular no Brasil e suas implicações para conservação. Tropical Conservation Science, vol. 3, no. 2, pp. 159-174.

ALVES, R.R. and ROSA, I.L., 2007. Zootherapy goes to town: the use of animal-based remedies in urban areas of NE and $\mathrm{N}$ Brazil. Journal of Ethnopharmacology, vol. 113, no. 3, pp. 541555. http://dx.doi.org/10.1016/j.jep.2007.07.015. PMid:17719192.

ALVES, R.R. and SANTANA, G.G., 2008. Use and commercialization of Podocnemis expansa (Schweiger 1812) (Testudines: Podocnemididae) for medicinal purposes in two communities in North of Brazil. Journal of Ethnobiology and Ethnomedicine, vol. 4, no. 1, pp. 3. http://dx.doi.org/10.1186/1746-4269-4-3. PMid:18208597.

ALVES, R.R.N. and ALVES, H.N., 2011. The faunal drugstore: animal-based remedies used in traditional medicines in Latin America. Journal of Ethnobiology and Ethnomedicine, vol. 7, no. 1, pp. 9. http://dx.doi.org/10.1186/1746-4269-7-9. PMid:21385357.

ALVES, R.R.N. and SOUTO, W.M.S., 2011. Ethnozoology in Brazil: current status and perspectives. Journal of Ethnobiology and Ethnomedicine, vol. 7, no. 1, pp. 22. http://dx.doi.org/10.1186/17464269-7-22. PMid:21767370.

ALVES, R.R.N., 2008. Animal-based remedies as complementary medicine in Brazil. Forschende Komplementarmedizin, vol. 15, no. 4, pp. 226-227. http://dx.doi.org/10.1159/000144178. PMid:18787332.

ALVES, R.R.N., 2009. Fauna used in popular medicine in Northeast Brazil. Journal of Ethnobiology and Ethnomedicine, vol. 5, no. 1, pp. 1. http://dx.doi.org/10.1186/1746-4269-5-1. PMid:19128461.

ALVES, R.R.N., LIMA, H.N., TAVARES, M.C., SOUTO, W.M.S., BARBOZA, R.R.D. and VASCONCELLOS, A., 2008. Animal-based remedies as complementary medicines in Santa Cruz do Capibaribe, Brazil. BMC Complementary and Alternative Medicine, vol. 8, no. 1, pp. 44. http://dx.doi.org/10.1186/14726882-8-44. PMid:18647413.

ALVES, R.R.N., NOGUEIRA, E.E.G., ARAUJO, H.F.P. and BROOKS, S.E., 2010a. Bird-keeping in the Caatinga, NE Brazil. Human Ecology, vol. 38, no. 1, pp. 147-156. http://dx.doi. org/10.1007/s10745-009-9295-5.

ALVES, R.R.N., SOUTO, W.M.S. and MOURÃO, J.S., 2010b. A Etnozoologia no Brasil: importância, status atual e perspectivas. Recife: NUPEEA. 550 p.

ALVES, R.R.N., BARBOZA, R.R.D. and SOUTO, W.M.S., 2010c. A global overview of canids used in traditional medicines. Biodiversity and Conservation, vol. 19, no. 6, pp. 1513-1522. http://dx.doi.org/10.1007/s10531-010-9805-1.

ALVES, R.R.N., ROSA, I.L. and SANTANA, G.G., 2007. The role of animal-derived remedies as complementary medicine in Brazil. Bioscience, vol. 57, no. 11, pp. 949-955. http://dx.doi. org/10.1641/B571107

ARAÚJO, H F.P. and NISHIDA, A.K., 2007. Conhecimento de pescadores artesanais sobre a composição da avifauna em estuários paraibanos: uma contribuição para a conservação. Sitientibus Série Ciências Biológicas, vol. 7, no. 1, pp. 67-77.

AYRES, M., AYRES-JÚNIOR, M. and AYRES, D.L., 2007. BioEstat: aplicações estatísticas nas áreas das ciências biomédicas. Belém: ONG Mamirauá.

BARTLETT, J.E., KOTRLIK, J.W. and HIGGINS, C.C., 2001. Organizational research: determining appropriate sample size 
in survey research. Information Technology, Learning and Performance Journal, vol. 19, no. 1, pp. 43-50.

BEGOSSI, A., SALYVONCHYK, S., NORA, V., LOPES, P.F. and SILVANO, R.A.M., 2012. The paraty artisanal fishery (southeastern Brazilian coast): ethnoecology and management of a social-ecological system (SES). Journal of Ethnobiology and Ethnomedicine, vol. 8, no. 1, pp. 22. http://dx.doi.org/10.1186/17464269-8-22. PMid:22738073.

BRASIL, 1998 [viewed 1 March 2013]. Lei $n^{\circ}$ 9.605, de 12 de fevereiro de 1998. Dispõe sobre as sanções penais e administrativas derivadas de condutas e atividades lesivas ao meio ambiente, $e$ dá outras providências. Diário Oficial da União [online], Brasília, 13 fev. Available from: http://www.planalto.gov.br/ccivil_03/ leis/19605.htm

CLAUZET, M., RAMIRES, M. and BEGOSSI, A., 2007. Etnoictiologia dos pescadores artesanais da praia de Guaibim,Valença (BA), Brasil. Neotropical Biology and Conservation, vol. 2, no. 3, pp. 136-154.

DESLANDES, S.F., CRUZ-NETO, O., GOMES, R. and MINAYO, M.C.S., 1994. Pesquisa social: teoria, método e criatividade. Petrópolis: Vozes.

DIXON-WOODS, M., SHAW, R.L., AGARWAL, S. and SMITH, J.A., 2004. The problem of appraising qualitative research. Quality \& Safety in Health Care, vol. 13, no. 3, pp. 223-225. http://dx.doi. org/10.1136/qshc.2003.008714. PMid:15175495.

FAVORETTO, B.C., RICARDI, R., SILVA, S.R., JACYSYN, J.F., FERNANDES, I., TAKEHARA, H.A. and FAQUIM-MAURO, E.L., 2011. Immunomodulatory effects of crotoxin isolated from Crotalus durissus terrificus venom in mice immunised with human serum albumin. Toxicon, vol. 57, no. 4, pp. 600-607. http://dx.doi. org/10.1016/j.toxicon.2010.12.023. PMid:21223974.

KITSON, G.C., SUSSMAN, M.B., WILLIAMS, G.K., ZEEHANDELAAR, R.B., SHICKMANTER, B.K., STEINBERGER, J.L., CAO, Y., WILLIAMS, D.D. and LARSEN, D.P., 2001. Comparison of ecological communities: the problem of sample representativeness. Ecological Monographs, vol. 72, pp. 41-56.

LEE, B., 2010. Exploring a new research method in diversity research. Procedia: Social and Behavioral Sciences, vol. 7, pp. 494-503. http://dx.doi.org/10.1016/j.sbspro.2010.10.067.

LOPES, P.F.M., FRANCISCO, A.S. and BEGOSSI, A., 2009. Artisanal commercial fisheries At the southern coast of São Paulo State, Brazil: ecological, social and economic structures. Interciencia, vol. 34 , no. 8, pp. 536-542.

MARKS, E.S., 1951. Some sampling problems in educational research. Journal of Educational Psychology, vol. 42, no. 2, pp. 85-96. http://dx.doi.org/10.1037/h0059821.

MARSHALL, M.N., 1996. Sampling for qualitative research. Family Practice, vol. 13, no. 6, pp. 522-525. http://dx.doi. org/10.1093/fampra/13.6.522. PMid:9023528.
MCCLATCHEY, W., 2006 [viewed 1 March 2013]. Improving the quality of international ethnobotany research and publications. Ethnobotany Research and Applications [online], vol. 4, pp. 1-10. Available from: http://hdl.handle.net/10125/231

MEDEIROS, M.F.T., SILVA, P.S. and ALBUQUERQUE, U.P., 2012. Quantification in ethnobotanical research: as overview of indices used from 1995 to 2009. Sitientibus Série Ciências Biológicas, vol. 11, no. 2, pp. 211-230. http://dx.doi.org/10.13102/scb108.

MEDEIROS, P.M., LADIO, A.H. and ALBUQUERQUE, U.P., 2014. Sampling problems in Brazilian research: a critical evaluation of studies on medicinal plants. Revista Brasileira de Farmacognosia, vol. 24, no. 2, pp. 103-109. http://dx.doi.org/10.1016/j.bjp.2014.01.010.

MOURÃO, J.S. and NORDI, N., 2006. Pescadores, peixes, espaço e tempo: uma abordagem Etnoecológica. Interciencia, vol. 31, no. 5 , pp. $358-363$

NASCIMENTO, D.M., FERREIRA, E.M., BEZERRA, D.M.M.S.Q., ROCHA, P.D., ALVES, R.R. and MOURÃO, J.S., 2012. Capture techniques' use of Caranguejo-uçá crabs (Ucides cordatus) in Paraíba state (northeastern Brazil) and its socio-environmental implications. Anais da Academia Brasileira de Ciências, vol. 84, no. 4, pp. 1051-1064. http://dx.doi.org/10.1590/S000137652012005000066 . PMid:23070129.

NISHIDA, A.K., NORDI, N. and ALVES, R.R.N., 2006. Mollusc gathering in northeast Brazil: an ethnoecological approach. Human Ecology, vol. 34, no. 1, pp. 133-145. http://dx.doi.org/10.1007/ s10745-005-9005-x.

RITTER, R.A., MONTEIRO, M.V., MONTEIRO, F.O., RODRIGUES, S.T., SOARES, M.L., SILVA, J.C., PALHA, M.D., BIONDI, G.F., RAHAL, S.C. and TOURINHO, M.M., 2012. Ethnoveterinary knowledge and practices at Colares Island, Pará state, eastern Amazon, Brazil. Journal of Ethnopharmacology, vol. 144, no. 2, pp. 346-352. http://dx.doi.org/10.1016/j.jep.2012.09.018. PMid:23000170.

SANTOS-FITA, D. and COSTA-NETO, E.M., 2007. As interações entre os seres humanos e os animais: a contribuição da etnozoologia. Biotemas, vol. 20, no. 4, pp. 99-110.

SILVANO, R.A. and VALBO-JØRGENSEN, J., 2008. Beyond fishermen's tales: contributions of fishers' local ecological knowledge to fish ecology and fisheries management. Environment, Development and Sustainability, vol. 10, no. 5, pp. 657-675. http:// dx.doi.org/10.1007/s10668-008-9149-0.

SPINDOLA, T. and SANTOS, R.S., 2003. Trabalhando com a história de vida: percalços de uma pesquisa(dora?). Revista da Escola de Enfermagem, vol. 37, no. 2, pp. 119-226.

ULYSSÉA, M.A., HANAZAKI, N. and LOPES, B.C., 2010. Insetos no folclore da comunidade do Ribeirão da Ilha, Florianópolis, Santa Catarina, Brasil. Sitientibus Série Ciências Biológicas, vol. 10, no. 2-4, pp. 244-251.

ZAR, J.H., 1996. Biostatistical analysis. New Jersey: PrenticeHall International Editions. 622 p. 